Article

\title{
Conditions for Sustainability of the Elephant Marsh Fishery in Malawi
}

\section{Ishmael B. M. Kosamu ${ }^{1,2}$}

1 The Polytechnic, Department of Physics and Biochemical Sciences, University of Malawi, Private Bag 303, Chichiri, Blantyre 3, Malawi; E-Mail: ikosamu@poly.ac.mw;

Tel.: +265-187-0411; Fax: +265-187-0578

2 Institute of Environmental Sciences (CML), Leiden University, P.O. Box 9518, 2300 RA Leiden, The Netherlands; E-Mail: kosamu@cml.leidenuniv.nl

Received: 12 March 2014; in revised form: 12 June 2014 / Accepted: 13 June 2014 /

Published: 26 June 2014

\begin{abstract}
The Elephant Marsh, a wetland in Southern Malawi, is important for small-scale fisheries. It is managed by local institutions, which are not formally linked to any state institutions. This paper uses qualitative comparative analysis (QCA) to examine factors for sustainability at 24 fishing villages around the wetland using a hypothesis that "If strong local institutions (with or without government support) exist in an environment where resource users take collective action, and there is no or minimal conflictive interference, small-scale fisheries become sustainable". It was revealed that the sustainability of small-scale fisheries management at Elephant Marsh relies heavily on the strength of local fisheries' committees. Future interventions on fisheries management at the resource should, therefore, pay particular attention to protecting and (re)building collective social capital, especially in the leadership of fisheries committees.
\end{abstract}

Keywords: small-scale fisheries; wetland; sustainability; local institutions; Elephant Marsh; conditions; governance; Malawi

\section{Introduction}

Small-scale fisheries (SSF) support the livelihood of over 180 million people in developing countries [1]. Despite their relative importance, studies on the management constituency of SSF in developing countries are limited. Most of the well-known studies have been done in developed countries where SSF are scarce [2,3]. The deficiency in downscaled studies has led most decision 
makers in developing countries to manage SSF using more generalized blueprint panaceas generated in developed countries.

Due to background developments, such as population growth, rural poverty, climate change, and market forces, the exploitation pressure on SSF is likely to increase. In such scenarios, Hardin [4] would propose that some regulatory authority (likely a central government mechanism) should come in to regulate the resource before the commons are overexploited. Indeed, in the early 1990s central states had put themselves at the center of managing common pool resources (CPR) [5] resulting in conflicts rather than sustainability [6]. One reason for the failure has been that centralized bureaucracies are often unable to respond to rapid social-ecological change [7]. As a result of the general failure of central governments to manage common pool resources, there has been a shift towards more participatory, joint management arrangements [8,9].

Joint management arrangements were engineered quite early in SSF [10] but have gained wide application in forest management [11]. The design of successful management arrangements in SSF is not simple and depends on the locally-based institutional "bricolage" that focuses on the necessary points of engagement between resource users and regulatory authorities, such as the central states [12,13].

For developing countries, the institutional design dilemma is compounded by the stratification of the social, economic, political and biodiversity landscapes. Several scholars [14-17] have questioned the rationale behind the adoption and implementation of "imported" institutions in systems that have been poorly understood. Nevertheless, most efforts in small-scale fisheries management in developing countries have put a lot of emphasis on setting up co-management arrangements. The approach in Africa, for example, has been a hasty, ceremonial, top-down devolution of some aspects of management from central states (which are usually weak) to local communities resulting in an imbalance of power and interests.

From the critical perspective of Ward and Weeks [18] and Carswell [19], it may be noted that the co-management discourse still justifies "raison d'être" of state regulators. Thus, the critical perspective leads to a research platform that can reveal instances where purely community-based fisheries management can be conceptualized along with the other management types. Hints that such research might be fertile are given, for instance, by Hara and Nielsen [14], who point out that co-management in Africa appears to be more of an illusion than an empowerment of local fishing communities and there is need to find some bold answers to its ability in achieving the objectives of all players. Even years after Ostrom's work [10], Jentoft et al. [16] also found it difficult to conceptualize the necessity of the state in the management of fisheries by mentioning that "an alternative agent like the state is not always needed and community level civil institutions play a greater role in fisheries management if they are allowed and equipped to do so". In some cases, however, informal institutional building can get support from centralized formal law like in the V-notch lobster program as reported by Acheson [20]. The good news though is that small-scale systems such as SSF are easier to drive to success than large-scale entities because of the reduced number of competing interests and minimal layers of organization [21].

The Elephant Marsh, a wetland in southern Malawi, is important for SSF and the management arrangements are quite informal. The wetland is managed by local institutions, which are not formally linked to any strong state institutions. Malawi also lacks a management framework strong enough to 
enforce a balanced and sustainable wetland development under rising pressures, such as overexploitation and agricultural conversion, which are mainly driven by population growth, rural poverty, climate change and market growth. In the Elephant Marsh, additional drivers include fluctuation in water levels caused mainly by hydroelectric power generation at Kapichira Dam and the abstraction of water for irrigation by Illovo sugar estate; both located upstream. Moreover, the coordination of the roles of the various stakeholders in wetland management at Elephant Marsh is not very clear or stable [22]. It is therefore important to determine factors of success for these locally-based management arrangements in order to achieve long-term sustainability of the fishery at Elephant Marsh and reflect upon optimal roles of the state.

Case studies from which lessons on SSF in developing countries can be drawn and applied to the Elephant Marsh Fishery are found, for example, in Chile, Comoros, Côte d'Ivoire, Malawi, India, Laos, Mexico, South Africa, Zambia, Zimbabwe, Senegal, and Nigeria [23-34]. While some are success stories, others are not. Experiences from Kafue Flats Floodplain Fishery in Zambia for instance, reveal that although central states promise many theoretical benefits when devising management arrangements, there is usually limited involvement and cost-benefit analysis of local group interests resulting in social resentment and consequent counter productivity [6,31]. However, it is interesting to note that in Malawi, for example, the formation of functional local institutions, which get support from the central state usually starts with a strong collective social capital. Although the Malawi government has taken a supportive role at lakes Chiuta, Malombe, and Chilwa, the fishery at Lake Chiuta is the only one that is striving due to the good social structures at local scale [26]. This is consistent with findings by Gutiérrez et al. [35] where fisheries management was not successful in communities with low social capital (probably due to internal stratification and hierarchies), even when there was continued government effort. Some cases, such as Lake Chilika in India [27], reveal an interesting scenario. While the state is not supportive and there are no co-management arrangements, the fishery is still a success because of a strong collective social capital. It is therefore logical to suggest that conditions of success for each fishery are unique and can only be established if the system in question has been thoroughly studied. This paper uses qualitative comparative analysis (QCA) to examine factors of success at 24 fishing villages around the wetland using a hypothesis that "If strong local institutions (with or without government support) exist in an environment where resource users take collective action, and there is no or minimal conflictive interference, small-scale fisheries become sustainable".

The next section reviews literature on small-scale fisheries management in developing countries and provides a basis for the variables used in the analysis. The third section provides the methods used and how the scores for each variable were generated. The fourth section gives results and discussion. The paper ends with some implications for future policy direction and small-scale fisheries management practice in developing countries.

\section{Small-Scale Fisheries Management in Developing Countries}

Being a form of resource extraction, capture fisheries usually do not continuously require high inputs after making the initial investment in the acquisition of the extraction equipment. Informally put, once you have the boat and fishing gear, you tend to go on fishing. Thus, the economics of 
extraction easily lead to over-exploitation of the resource. Moreover, capture fisheries usually start out as an open access situation and even if access is closed to only a restricted group, full privatization is usually impossible and the fisheries remain a common pool resource, hence, subject to the risk of Hardin's [4] "tragedy of the commons" that leads to resource exhaustion. Hardin [4] concluded that communal natural resources can only be sustained if a coercive central authority organizes the exploitation. Béné et al. [36] observed that "over-exploitation of a resource which is owned by many and not effectively managed by anyone, leads to reduction in catch and eventual poverty of users and others who would otherwise benefit from the harvests".

Capture fisheries are sometimes protected against over-exploitation by natural circumstances such as sheer size, inaccessibility or cold, as shown for instance in Brox [37] and Planque et al. [38]. In most cases however, small-scale capture fisheries, consisting for instance of inland water or tropical seas are seldom protected by natural means, thereby requiring strong institutions that can regulate extraction by humans and achieve sustainability of the resource. Such regulatory institutions can be locally based, state controlled or a crossbreed of the two in what is widely known as co-management.

In her book, "Understanding Institutional Diversity", Ostrom [39] defines institutions as rules, norms and shared strategies that mediate human behavior. From this perspective, it clear that the sustainability of SSF depends on a continuum of attributes that positively shape human actions towards a negotiated consensus on powers and responsibilities in relation to the fisheries resource at either supra-local level (e.g., existence of guiding legislation and policies from central government) or local level (e.g., leadership, power relations, benefit sharing). Several scholars [17,40-42] have decried the lack of recognition and involvement of small-scale local fishers in fisheries management, especially in developing countries. To achieve a balanced representation in decision-making, there is more shift to arrangements in which local communities and governments share responsibilities over a resource. Although the basic idea of such arrangements is to achieve equal power sharing (strong government versus strong communities), the application of the notion has varied widely especially in small-scale fisheries management where the socio-ecological context is quite complex and diverse [41,42]. Whatever the case, these partnerships require high levels of compliance from local communities and significant support, information sharing, consultation, advice and cooperation from government [43] in order to sustainably manage common pool resources. Ostrom [10] identified eight conditions for the success of managing common pool resources. The conditions are: (i) clearly defined boundaries around the resource; (ii) congruence between appropriation and provision rules and local conditions; (iii) collective-choice arrangements; (iv) monitoring; (v) graduated sanctions; (vi) conflict resolution mechanisms; (vii) minimal recognition of rights to organize; and (viii) nested enterprises. Based on earlier studies [22], the fishery at Elephant Marsh in Malawi can ably achieve the first two principles mainly due to a good collective social capital at resource level. Collective social capital, in this respect, is defined as the social capacity of groups, in terms of trust and institutions, to take collective action [13]. 
Table 1. Choice of the conditions of interest at the Elephant Marsh Fishery.

\begin{tabular}{|c|c|c|c|}
\hline $\begin{array}{c}\text { Ostrom's } \\
\text { Condition/Attribute }[10]\end{array}$ & $\begin{array}{l}\text { Definition of the } \\
\text { Condition/Attribute }\end{array}$ & $\begin{array}{c}\text { Variables that Define the Attribute/Condition } \\
\text { at the Elephant Marsh Fishery }\end{array}$ & $\begin{array}{l}\text { Current Status of the } \\
\text { Condition/Attribute at Elephant } \\
\text { Marsh/Justification for Inclusion } \\
\text { in the Study } \\
\end{array}$ \\
\hline $\begin{array}{l}\text { Clearly defined boundaries } \\
\text { at the resource }\end{array}$ & $\begin{array}{l}\text { Individuals or households who have rights to } \\
\text { withdraw resource units from the CPR must } \\
\text { be clearly defined, as must the boundaries of } \\
\text { the CPR itself }\end{array}$ & $\begin{array}{l}\text { Each fishing village has a defined boundary agreed upon } \\
\text { by fishers and their leadership, legitimate users (non- } \\
\text { outsiders) are known, and the external boundaries of the } \\
\text { wetland are clear. }\end{array}$ & Condition met [22] \\
\hline $\begin{array}{l}\text { Congruence between } \\
\text { appropriation and } \\
\text { provision rules and } \\
\text { local conditions }\end{array}$ & $\begin{array}{l}\text { Appropriation rules restricting time, place, } \\
\text { technology, and/or quantity of resource units } \\
\text { (in this case fish) are related to local } \\
\text { conditions and to provision rules requiring } \\
\text { labor, material, and/or money }\end{array}$ & $\begin{array}{l}\text { Fishers pay small amounts of money to obtain a fishing } \\
\text { license, get labor, purchase acceptable fishing gear, have } \\
\text { restricted periods of entry into the resource. }\end{array}$ & Condition met [22] \\
\hline $\begin{array}{l}\text { Collective choice } \\
\text { arrangements }\end{array}$ & $\begin{array}{l}\text { Most individuals affected by the operational } \\
\text { rules can participate in modifying the } \\
\text { operational rules }\end{array}$ & $\begin{array}{l}\text { Existence of local democracy, ability to influence or } \\
\text { change operational rules, Influence of the chief on choice } \\
\text { of fisheries committee leadership? Are women included in } \\
\text { the fisheries committee leadership? Boat theft or absence } \\
\text { of theft? Do community members trust each other? Are } \\
\text { fishers migrating to other fishing villages? For the local } \\
\text { situation at the Elephant Marsh, this is attainable if } \\
\text { collective social capital at village level is good. }\end{array}$ & Not clear before this study \\
\hline Monitoring & $\begin{array}{l}\text { Monitors who actively audit CPR conditions } \\
\text { and appropriator behavior are accountable to } \\
\text { the appropriators or are the appropriators }\end{array}$ & $\begin{array}{l}\text { Are the fisheries assistants from government/government } \\
\text { officers present? What is the impact of the presence of the } \\
\text { government officers? Does their presence have any impact } \\
\text { on the communities that use the CPR? Do the officers just } \\
\text { come to "police" or they inform and teach fishers other } \\
\text { things on fisheries management? }\end{array}$ & Not clear before this study \\
\hline
\end{tabular}


Table 1. Cont.

$\begin{array}{ccc}\text { Ostrom's } & \text { Definition of the } & \text { Variables That Define the Attribute/Condition } \\ \text { Condition/Attribute [10] } & \text { andition/Attribute } & \text { at the Elephant Marsh Fishery }\end{array}$

Appropriators who violate operational rules are likely to be assessed graduated

Graduated sanctions sanctions (depending on seriousness and context of the offense) by other appropriators, by officials accountable to these appropriators or by both

Appropriators and their officials have rapid low-cost local arenas to resolve conflicts among appropriators or between appropriators and officials.

Conflict resolution mechanism

The rights of the appropriators to devise

Minimal recognition of rights to organize their own institutions are not challenged by external government authorities

Appropriation, provision, monitoring, enforcement, conflict resolution and governance activities are organized in multiple layers of nested enterprises
Nested enterprises the fishery operating according to national guidelines? Is there cross-scale cooperation?
What the status of the local leadership in form of fisheries committee chairman? Actual implementation of the rules by the committee chair? Reputation of the committee chair (Knowledge and ability to act), Presence of own office space for the committee, are by-laws there for implementation, Does the implementation depend on extent/level of offence? Is this really done/ are the by-laws really implemented?

Current Status of the

Condition/Attribute at

Elephant Marsh/Justification

for Inclusion in the Study

Not clear before this study

Chiefs, fisheries committee leadership, government officials?

The hierarchy of conflict resolution (Chiefs, fisheries committee

leadership, government officials). Does the chief uphold the roles

Not clear before this study of the fisheries committee in conflict resolution?

Interference from state? Does the state challenge the right of users to create their own local institution? What roles do the government officers have? What is the optimal role of the

Not clear before this study state/government agents?

National guiding principles/ government officials? What is their level of support in policy direction and information sharing? Is

Not clear before this study 
Using evidence from several authors [44-46] and as highlighted by Ostrom's [10] list in Table 1, the sustainability of SSF at Elephant Marsh may also depend on several other factors in addition to a good collective social capital at resource level. For example the presence (or absence) of government officers and the leadership of local chiefs in conflict resolution mechanisms can either be positive if they uphold the roles of local fisheries management committees or negative if they calculatedly take a more "power defending" position (conflictive interference) [35,47]. Conflictive interference may consequently bring administrative difficulties and social divisions at resource level $[6,17,46]$.

It is therefore not surprising that most of the conditions on Ostrom's [10] list, especially the last six, are seldom attained in developing countries like Malawi. For instance, "Minimal recognition of rights to organize" necessitates legitimacy and strong recognition by central states of the locally constructed institutions while "nested enterprises" underscores the fact that central states are important for support (policy direction, information sharing) so that issues of cross scale cooperation can best be addressed. Wilson et al. [41] observe that local SSF management cannot be effective if it is not considered legitimate by stakeholders especially when central states are too weak to enforce formal rules for controlling activities of intruders and safeguarding supra-local values such as biodiversity and external ecosystem services. The overall result is usually voluntary compliance, which eventually disadvantages locals and erodes local institutions [6,40]. On the other hand, if central states fail to devolve power to local communities in joint management arrangements and consistently take a position of commanding, imposing and enforcing alien rules and regulations, the negotiated fulcrum is lost, sporadic illegal activities may emerge and the management system is likely to fail [17,48-52].

From the literature reviewed, it seems the management constituency of the Elephant Marsh fishery is built around collective social capital (which may depend on the leadership of the local fisheries committee or village chief), and the presence of a central state, which might be supportive (recognizing, helping, educating, informing, power sharing) or conflictive (imposing alien regulations). This paper seeks to provide some preliminary contribution to the importance of four factors namely: collective social capital at village level (CSC_V), collective social capital at local fisheries committee level (CSC_C), presence and influence of government agents (GOV), and the role of chiefs (CHF) in the success of local SSF management at Elephant Marsh in Malawi.

\section{Study Area}

Elephant Marsh is located on the East African Rift Valley floor in the southern part of Malawi $\left(14^{\circ} 25^{\prime}-17^{\circ} 50^{\prime} \mathrm{S}\right.$ and $\left.35^{\circ} 15^{\prime}-35^{\circ} 15^{\prime} \mathrm{E}\right)$, see Figure 1 . It covers an average area of about $600 \mathrm{~km}^{2}$, although actual size varies from about $2700 \mathrm{~km}^{2}$ in the wet season to $500 \mathrm{~km}^{2}$ in the dry season. The variation creates season-oriented pressure on the ecosystem goods and services that communities can draw from the wetland. The Elephant Marsh straddles the administrative districts of Chikhwawa and Nsanje, which fortunately follow similar institutional arrangements and therefore no major trans-district problems arise. The region has an average altitude of $500 \mathrm{~m}$ above sea level and an annual precipitation range of 560 to $960 \mathrm{~mm}$. The mean annual precipitation in Malawi is $1180 \mathrm{~mm}$ and the altitude ranges from 50 to $3000 \mathrm{~m}$ asl. The marsh is fed by the Shire River, the only outlet of Lake Malawi, which flows through it in a southerly direction before joining the Zambezi River in Mozambique. 
Figure 1. Map of the Elephant Marsh showing the location of the fishing villages.

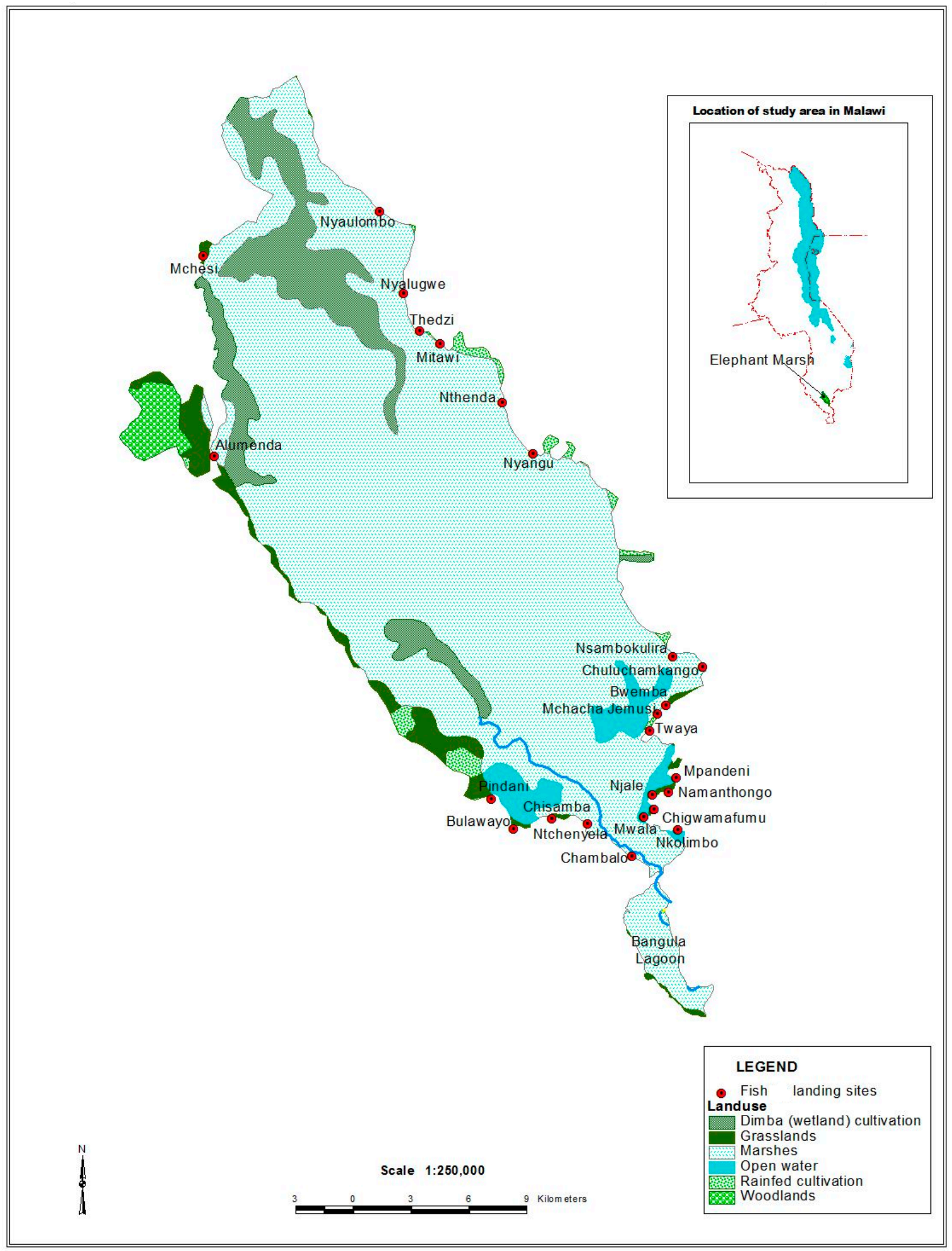


The marsh has relatively grassy margins but the bulk of its surface is formed by a mosaic of rooted swamp vegetation (sudd), floating vegetation and open water. In the southern part, this pattern is interspersed with islands with saline soils and palm trees. The Elephant Marsh is also home to several species of fish, out of which Clarias gariepinus (locally known as mlamba), Oreochromis mossambicus (chambo), Oreochromis placidus (makumba), and Barbus ssp. (matemba) comprise over $90 \%$ of the commercial catch [22].

The International Union for Conservation of Nature (IUCN) red list identifies Rynchops flavirostris (African skimmer) and Oreochromis mossambicus (chambo) as species under threat in its natural range while the Convention on International Trade in Endangered Species (CITES) list includes Crocodylus niloticus (Nile crocodile) and Hippopotamus amphibius (hippopotamus). The Elephant Marsh is therefore a very important habitat for these species.

The annual fish production from around the Elephant Marsh has been estimated at an average of 8500 tons [22]. This figure possibly includes the lower sections of the Shire River downstream from Elephant Marsh but generally indicates an annual production of $141.7 \mathrm{~kg} / \mathrm{ha}$. There are no recent data on the trends of fisheries exploitation at the Elephant Marsh partly due to lack national interest in carrying out research on common pool resources such as the Elephant Marsh. Unfortunately, such data is very important for future impact assessment studies.

Management arrangements at Elephant Marsh are guided by customary law. At village level and under guidance of a traditional chief, each development sector is represented in the form of an executive committee that is responsible for coordination of specific activities. In the fisheries sector, the village level committee is called a Beach Village Committee (BVC), which also controls access to the Elephant Marsh through Beach Chairs. Some twenty-four fisheries committees are found around Elephant Marsh. Based on our field visits in 2013, the arrangement appears to be working well based on community membership of the wetland users. Immigrants are restricted from access to the wetland but are allowed, for example, as fish traders and processors. In most cases, they are easily identified and referred to as "Angoni" meaning "outsider" (although Angoni is a name of an ethnic group).

\section{Methodology}

\subsection{Research Variables}

The present study focuses on analysis of success and failure factors for sustainable SSF in at the Elephant Marsh Fishery using crisp set qualitative comparative analysis (csQCA). Data were collected between April and November, 2013. The preceding literature review (Section 2) has indicated that these success and failure factors should at minimum include: (i) the collective social capital of the fisheries committee; (ii) the collective social capital of the fishing village; (iii) the presence of government agents and their influence; (iv) how the chief of the village is involved in fisheries management (conflictive or supportive role); and (v) the overall status of the fishery (outcome) in terms of sustainability. Sustainability in this respect is looked at with the assumption that it is not attributable to variations related to climate, river discharge, or decline from original to sustainable yield levels. Data for all the five variables were collected through focus group discussions, interviews, and observations. Triangulation was attained by using emic (insiders' view) and etic (researchers' 
impression) approaches. The following is a summary of the main attributes that were looked at to come up with a score of either (0) for failure or (1) for success. The general guideline was to have a strict cut-off between 0 and $1 \mathrm{~s}$.

i. Collective social capital for committee: The actions of the fisheries committee are motivated by several factors including reputation of the leader and communal value attached to fish. This variable was quantified using five attributes: (i) the etic (researchers' impression) of the quality of the fisheries committee chairperson (knowledge and ability to act); (ii) presence of own fund at fisheries committee level; (iii) availability of a committee-owned structure (building for meetings/office); (iv) presence of written by-laws; and (v) the actual implementation of graduated sanctions to offenders by fisheries committee. Each attribute had a score of 1 resulting in an overall additive maximum of 5 points. As an input variable for data analysis the 5 points were assessed as a score of (1) while anything lower was assessed as (0).

ii. Collective social capital for the village: When community cohesion is strong, achievement of a common purpose is easier than in an environment of conflict. The score for this attribute was based on (i) collective community effort to keep the sanitary conditions of the beach clean and the existence of local democracy; (ii) boat safety/absence of theft; (iii) inclusiveness of females at the beach (e.g., as fish processors and traders); (iv) willingness to explore trust-based investment (e.g., fishers to give their catch of the day to a trader for sale at a market and only get proceeds after the trader has sold the fish); and (v) migration of fishers to other villages for fishing reasons, (indicator of a "bad beach"). Each attribute had a score of 1 resulting in an overall additive maximum of 5 points. As an input variable for data analysis the 5 points were assessed as a score of (1) while anything lower was assessed as (0).

iii. Government visits and impact: The score for this attribute was based on the frequency of official visits by government agents and the impact of what they do during the visits. According to Malawi's Department of Fisheries, government agents are supposed to visit a beach at least twice a month for extension activities. This essentially translates to a minimum of 24 possible visits in a year. The impact of the visits was measured at three levels: (i) "come and look" gave an impact factor of 1; (ii) "come, look and police" gave an impact factor of 2; while (iii) "come, look, teach/inform and police" gave an impact factor of 3. A final score was generated by multiplying the number of visits in a year by the impact factor to give a minimum positive impact score of 72 points (i.e., $24 \times 3$ ). As an input variable for data analysis 72 points or more (if there was a higher frequency of visits) were assessed as a score of (1) while anything lower was assessed as (0).

iv. Chief's support: Due to the customary arrangement, the chief is important in upholding the roles of the fisheries committee. The score for this attribute was based on whether the chief is supportive or in conflict with the affairs of the fishing site, especially the fisheries committee using three indicators (i) etic impression (e.g., from stories of conflict or other negative allusions); (ii) opinion of fishers, traders and fish processors and (iii) opinion of government officials. Each indicator had a score of 1 resulting in an overall additive maximum of 3 points. As an input variable for data analysis the 3 points were assessed as a score of (1) while anything lower was assessed as (0). 
v. Sustainability: The score for this attributes is based on the researchers' objective assessment [53] and insiders' view (emic) of four indicators (i) stability of catch (abundance overfishing); (ii) quality of catch (non-juveniles for the late maturing Oreochromis and Tilapia species); (iii) trends in the catch per unit effort (CPUE); and (iv) the ability to keep non-community members (immigrants) out of the resource. Each attribute had a score of 1 resulting in an overall additive maximum of 4 points. As an input variable for data analysis the 4 points were assessed as a score of (1) while anything lower was assessed as (0).

\subsection{Qualitative Comparative Analysis and the Defining Variables}

Qualitative Comparative Analysis (QCA) focuses on linking an outcome to casual configurations, which are considered as explanatory conditions. There are three QCA techniques (based on set theory and Boolean algebra) namely: Multivariate QCA, crisp set QCA, and fuzzy set QCA. As indicated earlier, this paper uses crisp set QCA because of its ability to portray multiple causal combinations including minority effects. A crisp set is a condition in which a case may be interpreted, based only on two possible outcomes ( 0 or 1$)$ expressed as either in or out; true or false; yes or no. For example, a specific fishery might be successful (1) or not (0) if there is a conflictive village chief. The limitation with csQCA is that the method does not allow for intermediate scenarios because it is case-based. Table 1 specifies the definition of each of the variables in formal terms.

\subsection{Crisp Set QCA and an Overview of the Case Studies}

Crisp set QCA is done in six steps [54-56] using TOSMANA (Tool for Small-N Analysis) version 1.3.2.0 [57]. It allows a direct conversion of hypotheses into variables (Table 2), which are relevant for all the cases, followed by building of a raw dataset for the cases (Table 3 ) and construction of a truth table. The third step involves resolving contradictory configurations (outcomes that lead to 0 for some observed cases and 1 for other cases) before performing Boolean minimization (Step 4), which helps to clarify and simplify complex expressions of causal configurations. Step 5 identifies the logical remainders (combinations that are possible but have not been observed among the cases). The truth table and overall result of the analysis (Box 1) are automatically generated by TOSMANA (Step 6). The fishing villages are presented based on their location (East or West) on the banks of the marsh.

Table 2. The variables.

\begin{tabular}{llll}
\hline Variable & Abbreviation & Definition & Score \\
\hline Collective social capital_committee & CSC_C & $\begin{array}{l}\text { Strong collective social capital at } \\
\text { local fisheries committee level }\end{array}$ & 0 or 1 \\
\hline Collective social capital_village & CSC_V & $\begin{array}{l}\text { strong collective social capital at } \\
\text { village level }\end{array}$ & 0 or 1 \\
\hline Government Agents & GOV & $\begin{array}{l}\text { Presence and influence of } \\
\text { government agents }\end{array}$ & 0 or 1 \\
\hline Village chief & CHF & Chief is in conflict the community & 0 or 1 \\
\hline Outcome & OTM & Fishery is sustainable & 0 or 1 \\
\hline
\end{tabular}


Table 3. The dataset for the 24 fishing villages.

\begin{tabular}{cccccccc}
\hline Case ID & Name of Beach & Location & CSC_C & CSC_V & GOV & CHF & OTM \\
\hline I & Nkolimbo & East Bank & 0 & 0 & 1 & 0 & 0 \\
\hline II & Mwala & East Bank & 1 & 0 & 0 & 1 & 1 \\
\hline III & Chigwamafumu & East Bank & 1 & 1 & 0 & 1 & 1 \\
\hline IV & Njale & East Bank & 1 & 1 & 1 & 1 & 1 \\
\hline V & Namanthongo & East Bank & 0 & 1 & 0 & 1 & 0 \\
\hline VI & Mpandeni & East Bank & 0 & 0 & 1 & 0 & 0 \\
\hline VII & Twaya & East Bank & 0 & 1 & 0 & 1 & 0 \\
\hline VIII & Mchachajemusi & East Bank & 1 & 1 & 1 & 1 & 1 \\
\hline IX & Bwemba & East Bank & 0 & 0 & 1 & 0 & 0 \\
\hline X & Chuluchamkango & East Bank & 1 & 0 & 1 & 0 & 1 \\
\hline XI & Nsambokulira & East Bank & 1 & 1 & 0 & 1 & 1 \\
\hline XII & Nyangu & East Bank & 0 & 1 & 1 & 0 & 0 \\
\hline XIII & Nthenda & East Bank & 0 & 0 & 1 & 0 & 0 \\
\hline XIV & Mitawi & East Bank & 1 & 0 & 1 & 1 & 1 \\
\hline XV & Thedzi & East Bank & 1 & 1 & 1 & 1 & 1 \\
\hline XVI & Nyalugwe & East Bank & 0 & 0 & 0 & 1 & 0 \\
\hline XVII & Nyaulombo & East Bank & 1 & 1 & 1 & 1 & 1 \\
\hline XVIII & Mchesi & West Bank & 0 & 0 & 0 & 1 & 0 \\
\hline XIX & Alumenda & West Bank & 1 & 1 & 0 & 1 & 1 \\
\hline XX & Pindani & West Bank & 1 & 1 & 1 & 0 & 1 \\
\hline XXI & Bulawayo & West Bank & 0 & 0 & 1 & 0 & 0 \\
\hline XXII & Chisamba & West Bank & 1 & 1 & 1 & 1 & 1 \\
\hline XXIII & Ntchenyela & West Bank & 0 & 0 & 1 & 1 & 0 \\
\hline XXIV & Chambalo & West Bank & 0 & 1 & 1 & 1 & 0 \\
\hline & & & & & & &
\end{tabular}

\section{Results and Discussion}

From Table 3, one can easily deduce that that the dataset is simple enough to manually analyze the trends without the use of csQCA. For example, in all cases where CSC_C $=0$, there is no sustainability irrespective of a positive score for a good collective social capital of the village, presence and influence of government agents or a conflictive chief but when CSC_C $=1$, there is always sustainability. The csQCA is still used however to have more formal certainties.

Using csQCA, the truth table of the 24 cases generated in the TOSMANA Analytical Report (Box 1) shows that different configurations (sustainability and non-sustainability) could be found among the empirical cases.

The output is read as: sustainable small-scale fisheries management at Elephant Marsh is observed in fishing villages (II, III, XI, XIX, IV, VIII, XV, XVII, XXII, X, XIV, XX) that have a strong collective social capital at fisheries committee level (COLLECTIVE SOCIAL CAPITAL_ COMMITTEE $\{1\})$. 
Box 1. The overall output of the analytical process.

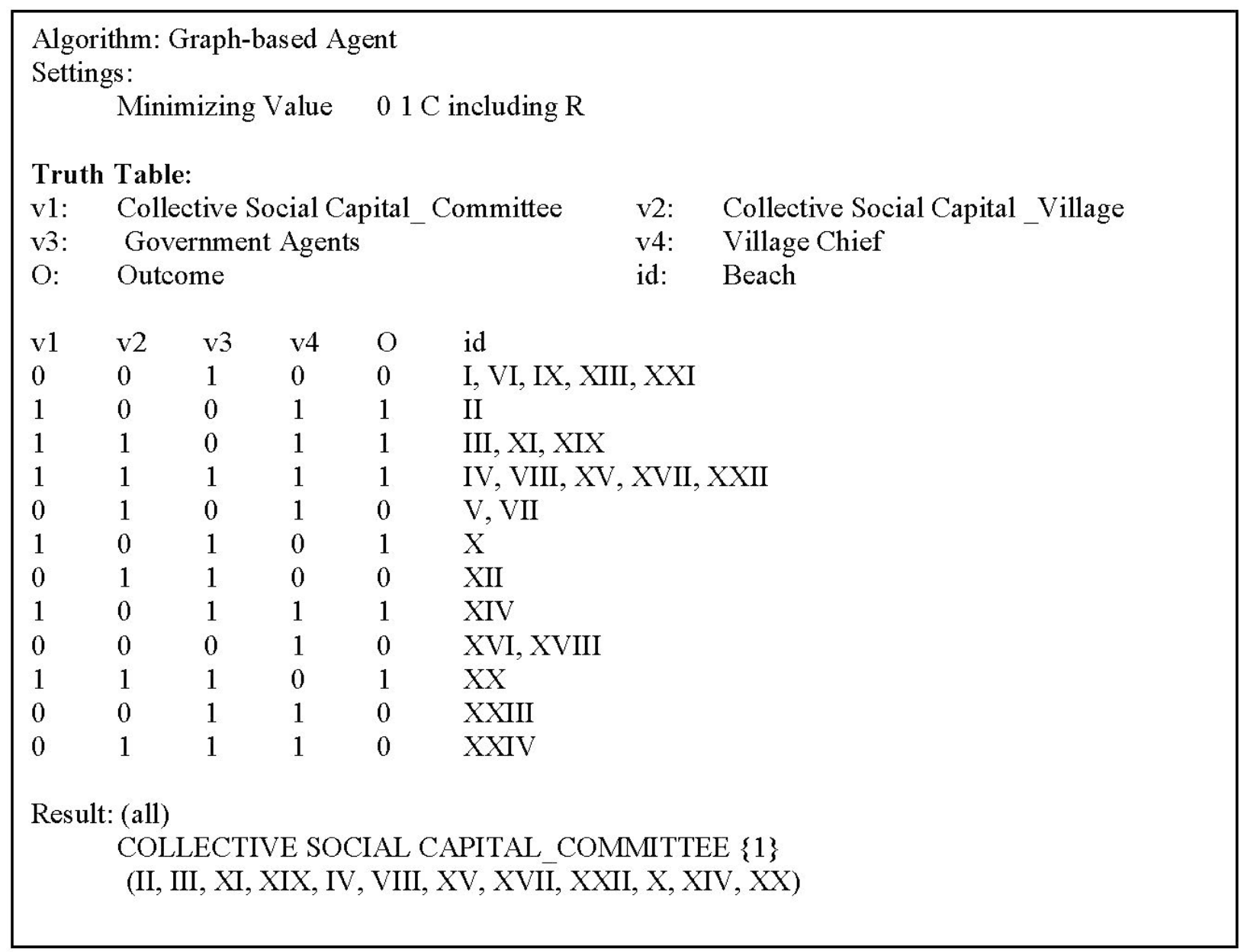

The overall result from this study has revealed that a good collective social capital at the fisheries committee level is the key factor in determining sustainability of locally-based wetland fisheries management at the Elephant Marsh. In most cases, weak economies like Malawi have very low financial capacity to support fisheries management activities at community level. The lack of material and financial resources forces the agents to be simultaneously present or absent [6], thereby creating shortfalls in the effectiveness of management programs. This study has underscored that the presence of government agents in itself does not contribute much to fisheries sustainability. Policy makers should therefore shift their effort towards establishment and strengthening of capable local leadership, which can spearhead community interests and ensure the sustainability of a resource. As most scholars $[11,17,46]$ have observed, one of the major challenges in establishing efficient local management structures in Malawi is the question of power sharing between village heads and fisheries committee leadership. At Lake Chilwa Fishery in Malawi, for example, there are 43 fishing committees and access is controlled through issuing of licenses from the Department of Fisheries (DoF) and the enforcement of local rules is done by the committees. However, there are reported power struggles between the local chiefs and the fisheries committee leadership resulting in weak social relations that jeopardize the sustainability of the fishery [26]. Nielsen et al. [58] also pointed out that the involvement of chiefs in SSF can be a delicate matter because local chiefs do not always operate in ways that fit well with transparency and participatory decision-making arrangements. In all 
but two (Chuluchamkango and Pindani) fishing villages at Elephant Marsh, the inability of the village chiefs to devolve some of their power to local fisheries committee leadership resulted in failure of a fishery. It is not surprising therefore to note that collective social capital at village level was disintegrated at almost all sites where the chief was conflictive. Similar observations have been made at Kafue Flats Fishery in Zambia [31]. At the same time it is interesting to note that good collective social capital at village level did not automatically translate into good leadership at the fisheries committee level. Many scholars have warned against the tendency of assuming group homogeneity in community structures that exhibit good collective social capital $[41,42,44]$. While it is difficult at this moment to rule out the influence of government agents in the management of SSF at Elephant Marsh, it is clear that future efforts in making the Elephant Marsh fishery a success seem to dwell more on identifying good local leaders, grooming them to build or strengthen the existing collective social capital, and encouraging cross-scale interactions amongst all fishing villages around the wetland so that sustainability of the common resource can safeguarded. It should also be realized that building such well-organized social systems for SSF management takes time [21]. There is, therefore, need to develop novel approaches, which can accommodate popular communal transformation of resource users under the guidance of a motivated and trusted local leader. Culturally, Malawians are reluctant to individually challenge decisions made through community consensus [1] and that makes it easier for a group to "silently" stand against unpopular, unilateral decisions, which a village chief can make [26,51]. It is therefore not strange that in some cases successful local committees were found in villages where the chiefs are conflictive. These findings reinforce the notion by Basurto [29] that when there is good local leadership at resource scale, local communities are able to organize themselves and develop efficient local management systems that can avoid the overexploitation of SSF even when support from central states is limited. One point to consider though is that in most parts of the world, even in countries with the highest literacy levels, fishers tend to attain lower levels of education [26], hence, most central states are reluctant to give them power and accept that they have the ability to organize themselves and sustainably manage a resource.

\section{Conclusions}

The sustainability of small-scale fisheries management at Elephant Marsh in Malawi depends on building strong local institutions with motivated leadership that can safeguard the interests of resource users. Future practice and policy directions on fisheries management at Elephant Marsh should understand the relevance of concrete local community trust, networks, norms plus values and strive to streamline them in decision making and policy formulation. The government of Malawi should begin to take a more participatory position in designing locally crafted working institutions for the sustainability of common pool resources, such as small-scale fisheries at Elephant Marsh. In villages where fisheries fail due to weak local institutions or conflictive chiefs, the imposition of fishing rules is futile. Feasible government reaction seems to lie in (re)building collective social capital, especially the leadership of a fisheries committees and formally linking the established local institutions to the central government structure. 


\section{Acknowledgments}

The author would like to thank the Malawi Government through University of Malawi Scholarship Programme and Leiden University (Institute of Environmental Sciences) through the Louwes Fund for supporting this research.

\section{Conflicts of Interest}

The author declares no conflict of interest.

\section{References}

1. Evans, L.; Andrew, N.L. Diagnosis and the management constituency of small-scale fisheries. In Small-Scale Fisheries Management: Frameworks and Approaches for the Developing World; CAB International: Oxfordshire, UK, 2011; pp. 35-58.

2. Ratner, B.D.; Oh, E.J.; Pomeroy, R.S. Navigating change: Second-generation challenges of small-scale fisheries co-management in the Philippines and Vietnam. J. Environ. Manag. 2012, 107, 131-139.

3. Blaikie, P. Is small really beautiful? Community-based natural resource management in Malawi and Botswana. World Dev. 2006, 34, 1942-1957.

4. Hardin, G. The tragedy of the commons. Science 1968, 62, 1243-1248.

5. Pomeroy, R.S.; Viswanathan, K.K. Experiences with fisheries co-management in Southeast Asia and Bangladesh. In The Fisheries Co-Management Experience: Accomplishments, Challenges, and Prospects; Wilson, D.C., Nielsen, J.R., Degnbol, P., Eds.; Kluwer Academic Publishers: Dordrecht, The Netherlands, 2003, pp. 99-117.

6. Chabwela, H.; Haller, T. Governance issues, potentials and features of participatory collective action in the Kafue flats. Int. J. Commons 2010, 4, 621-642.

7. Folke, C.; Hahn, T.; Olsson, P.; Norberg, J. Adaptive governance of social-ecological systems. Annu. Rev. Environ. Resour. 2005, 30, 441-473. doi:10.1146/annurev.energy.30.050504.144511.

8. Napier, V.R.; Branch, G.M.; Harris, J.M. Evaluating conditions for successful co-management of subsistence fisheries in KwaZulu-Natal, South Africa. Environ. Conserv. 2005, 32, 165-177.

9. Pomeroy, R.S.; Katon, B.M.; Harkes, I. Conditions affecting the success of fisheries co-management: Lessons from Asia. Mar. Policy 2001, 25, 197-208.

10. Ostrom, E. Governing the Commons: The Evolution of Institutions for Collective Action; Cambridge University Press: Cambridge, UK, 1990.

11. Zulu, L.C. Neo-liberalization, decentralization and community-based natural resources management in Malawi: The first sixteen years and looking ahead. Prog. Dev. Stud. 2012, 12, 193-212.

12. Russell, A.J.M.; Dobson, T.; Wilson, J.G.M. Fisheries management in Malawi: A patchwork of traditional, modern, and post-modern regimes unfolds. In International Governance of Fisheries Ecosystems: Learning from the Past, Finding Solutions for the Future; Schechter, M.G., Leonard, N.J., Taylor, W.W., Eds.; American Fisheries Society: Bethesda, MD, USA, 2008; pp. 53-98.

13. Lankhorst, M.; de Groot, W.T. The Importance of Engaging with and Building on Local Institutions for PES and REDD Effectiveness; Leiden University: Leiden, The Netherlands, 2012. 
14. Hara, M.; Nielsen, J.R. Experiences with fisheries co-management in Africa. In The Fisheries Co-Management Experience: Accomplishments, Challenges, and Prospects; Wilson, D.C., Nielsen, J.R., Degnbol, P., Eds.; Kluwer Academic Publishers: Dordrecht, The Netherlands, 2003; pp. 81-97.

15. Ribot, J.C.; Ashwini, C.; Lankina, T. Introduction: Institutional choice and recognition in the formation and foundation of local democracy. Conserv. Soc. 2008, 6, 1-11.

16. Jentoft, S.; Mikalsen, K.H.; Hernes, H.K. Representation in fisheries co-management. In The Fisheries Co-Management Experience: Accomplishments, Challenges, and Prospects; Wilson, D.C., Nielsen, J.R., Degnbol, P., Eds.; Kluwer Academic Publishers: Dordrecht, The Netherlands, 2003; pp. 281-292.

17. Béné, C.; Belal, E.; Baba, M.O.; Ovie, S.; Raji, A.; Malasha, I.; Njaya, F.; Andi, M.N.; Russell, A.; Neiland, A. Power struggle, dispute and alliance over local resources: Analyzing 'democratic' decentralization of natural resources through the lenses of Africa inland fisheries. World Dev. 2009, 37, 1935-1950.

18. Ward, W.; Weeks, P. Resource managers and resource users: Field biologists and stewardship. In Folk Management in the World's Fisheries; Dyer, C.L., McGoodwin, J., Eds.; University Press of Colorado: Boulder, CO, USA, 1994; pp. 91-113.

19. Carswell, G. Continuities in environmental narratives: The case of Kabale, Uganda, 1930-2000. Environ. Hist. 2003, 9, 3-29.

20. Acheson, J.M. Where have all the exploiters gone? Co-management of the Maine Lobster Industry. In Common Property Resources: Ecology and Community-Based Sustainable Development; Berkes, F., Ed.; Balhaven Press: London, UK, 1989; pp. 199-217.

21. Armitage, D.R.; Plummer, R.; Berkes, F.; Arthur, R.I.; Charles, A.T.; Davidson-Hunt, I.J.; Diduck, A.P.; Doubleday, N.C.; Johnson, D.S.; Marschke, M.; et al. Adaptive co-management for social-ecological complexity. Front. Ecol. Environ. 2009, 6, 95-102.

22. Kosamu, I.B.M.; de Groot, W.; Kambewa, P.S.; de Snoo, G.R. Institutions and ecosystem-based development potentials of the Elephant Marsh, Malawi. Sustainability 2012, 4, 3326-3345. doi:10.3390/su4123326.

23. Castilla, J.C.; Fernández, M. Small-scale benthic fisheries in Chile: On co-management and sustainable use of benthic invertebrates. Ecol. Appl. 1998, 8, S124-S132.

24. Hauzer, M.; Dearden, P.; Murray, G. The effectiveness of community-based governance of small-scale fisheries, Ngazidja Island, Comoros. Mar. Policy 2013, 38, 346-354.

25. Njifonjou, Q.; Satia, B.; Angaman, K. Fisheries co-management and poverty alleviation in the context of the sustainable livelihoods approach: A case study in the fishing communities of Aby lagoon in Coted'Ivoire. Int. J. Sustain. Dev. World Ecol. 2006, 13, 448-458.

26. Njaya, F.J. Governance of Lake Chilwa common pool resources: Evolution and conflicts. Dev. South. Afr. 2009, 26, 663-676. doi:10.1080/03768350903181431.

27. Sekhar, N.U. Social Capital and Fisheries Management: The Case of Chilika Lake in India. Environ. Manag. 2007, 39, 497-505. doi:10.1007/s00267-006-0183-0.

28. Baird, I.G.; Flaherty, M.S. Mekong River Fish Conservation Zones in Southern Laos: Assessing Effectiveness Using Local Ecological Knowledge. Environ. Manag. 2005, 36, 439-454. doi:10.1007/s00267-005-3093-7. 
29. Basurto, X. How locally designed access and use controls can prevent the tragedy of the commons in a Mexican small-scale fishing community. J. Soc. Nat. Res. 2005, 18, 643-659. doi:10.1080/08941920590959631.

30. Hauck, M.; Sowman, M. Coastal and Fisheries co-management in South Africa: An Overview and Analysis. Mar. Policy 2001, 25, 171-185.

31. Haller, T.; Merten, S. "We are Zambians_-Don't tell us how to fish!" Institutional Change, Power Relations and Conflicts in the Kafue Flats Fisheries in Zambia. Hum. Ecol. 2008, 36, 699-715. doi:10.1007/s10745-008-9191-4.

32. Jackson, J.; Muriritirwa, W.; Nyikahadzoi, K.; Sen, S. Analysis of emerging co-management arrangements in Zimbabwean inshore fisheries of Lake Kariba. In Fisheries Co-Management in Africa, In Proceedings from a Regional Workshop on Fisheries Co-Management Research, Mangochi, Malawi, 18-20 March 1997; Norman, A.K., Nielsen, J.R., Sverdrup-Jensen, S., Eds.; Innovative Fisheries Management (IFM): Aalborg, Denmark, 1998.

33. Gaspart, F.; Platteau, J.P.; de la Vierge, R. Heterogeneity and collective action for effort regulation: Lessons from the Senegalese small-scale fisheries. In Inequality, Cooperation, and Environmental Sustainability; Baland, J., Pranab, K.B., Samuel, B., Eds.; Princeton University Press: Princeton, NJ, USA, 2007, pp. 159-204.

34. Neiland, A.E.; Madakan, S.P.; Béné, C. Traditional Management Systems, Poverty and Change in the Arid Zone Fisheries of Northern Nigeria. J. Agrar. Chang. 2005, 5, 117-148. doi:10.1111/ j.1471-0366.2004.00096.x.

35. Gutiérrez, N.L.; Hilborn, R.; Defeo, O. Leadership, social capital and incentives promote successful fisheries. Nature 2011, 470, 386-389. doi:10.1038/nature09689.

36. Béné, C.; Hersoug, B.; Allison, E.H. Not by Rent Alone: Analysing the Pro-Poor Functions of Small-Scale Fisheries in Developing Countries. Dev. Policy Rev. 2010, 28, 325-358. doi:10.1111/j.1467-7679.2010.00486.x.

37. Brox, O. The common property theory: Epistemological status and analytical utility. Hum. Organ. 1990, 49, 227-235.

38. Planque, B.; Fromentin, J.M.; Cury, P.; Drinkwater, K.F.; Jennings, S.; Perry, I.; Kifani, S. How does fishing alter marine populations and ecosystems sensitivity to climate? J. Mar. Syst. 2010, 79, 403-417.

39. Ostrom, E. Understanding Institutional Diversity; Princeton University Press: Princeton, NJ, USA, 2005.

40. Sowman, M.; Scott, D.; Green, L.J.F.; Hara, M.M.; Hauck, M.; Kirsten, K.; Paterson, B.; Raemaekers, S.; Jones, K.; Sunde, J.; et al. Shallow waters: Social science research in South Africa's marine environment. Afr. J. Mar. Sci. 2013, 35, 385-402.

41. Wilson, D.C.; Raakjær, J.; Degnbol, P. Local ecological knowledge and practical fisheries management in the tropics: A policy brief. Mar. Policy 2006, 30, 794-801.

42. Castello, L.; McGrath, D.G.; Beck, P.S. Resource sustainability in small-scale fisheries in the Lower Amazon floodplains. Fish. Res. 2011, 110, 356-364.

43. Pomeroy, R.S. Small-scale fisheries management and development: Towards a community-based approach. Mar. Policy 1991, 15, 39-48.

44. Allison, E.H.; Ellis, F. The livelihoods approach and management of small-scale fisheries. Mar. Policy 2001, 25, 377-388. 
45. Evans, L.; Cherrett, N.; Pemsl, D. Assessing the impact of fisheries co-management interventions in developing countries: A meta-analysis. J. Environ. Manag. 2011, 92, 1938-1949.

46. Sen, S.; Nielsen, J. Fisheries co-management: A comparative analysis. Mar. Policy 1996, 20, 405-407.

47. Hviding, E.; Baines, B.G. Community-based fisheries management, tradition and the challenges of development in Marovo, Solomon Islands. Dev. Chang. 1994, 25, 13-39. doi:10.1111/j.14677660.1994.tb00508.x.

48. Béné, C. When fishery rhymes with poverty: A first step beyond the old paradigm on poverty in small-scale fisheries. World Dev. 2003, 31, 949-975.

49. Njaya, F.; Donda, S.; Bene, C. Analysis of power in fisheries co-management: Experiences from Malawi. J. Soc. Nat. Resour. 2012, 25, 652-666.

50. Eggen, Ø. Chiefs and everyday governance: Parallel state organisations in Malawi. J. South. Afr. Stud. 2011, 37, 313-331. doi:10.1080/03057070.2011.579436.

51. Pomeroy, R.S.; Berkes, F. Two to tango: The role of government in fisheries co-management. Mar. Policy 1997, 21, 465-480.

52. Isaacs, M. Recent progress in understanding small-scale fisheries in Southern Africa. Curr. Opin. Environ. Sustain. 2012, 4, 338-343.

53. Reichertz, J. Objective hermeneutics and hermeneutic sociology of knowledge. In A Companion to Qualitative Research; Flick, U., von Kardorff, E., Steinke, I., Eds.; Sage Publications: London, UK, 2004; pp. 290-295.

54. Rihoux, B.; de Meur, G. Crisp-set qualitative comparative analysis (csQCA). In Configurational Comparative Methods: Qualitative Comparative Analysis (QCA) and Related Techniques; Rihoux, B., Ragin, C.C., Eds.; Sage: Thousand Oaks, CA, USA, 2009; pp. 33-68.

55. Rihoux, B. QCA, 25 Years after "The Comparative Method": Mapping, Challenges, and Innovations-Mini-Symposium. Polit. Res. Q. 2013, 66, 167-235. doi:10.1177/1065912912468269.

56. Marx, A. Crisp-set qualitative comparative analysis (csQCA) and model specification: Benchmarks for future csQCA applications. Int. J. Mult. Res. Approaches 2010, 4, 138-158. doi:10.5172/mra.2010.4.2.138.

57. Cronqvist, L. Tosmana: Tool for SMAll-N Analysis. Available online: http:/tu-dresden.de/ die_tu_dresden/fakultaeten/philosophische_fakultaet/ifpw/polsys/lehre/lva/folder.2005-1123.0489976133/Fraktionsdisziplin/tosmana.pdf (accessed on 24 January 2014).

58. Nielsen, J.R.; Degnbol, P.; Viswanathan, K.K.; Ahmed, M.; Hara, M.; Abdullah, N.M.R. Fisheries co-management-An institutional innovation? Lessons from South East Asia and Southern Africa. Mar. Policy 2004, 28, 151-160.

(C) 2014 by the author; licensee MDPI, Basel, Switzerland. This article is an open access article distributed under the terms and conditions of the Creative Commons Attribution license (http://creativecommons.org/licenses/by/3.0/) 